\title{
Long-term management is needed for conserving plant diversity in a Wadden Sea salt marsh
}

\author{
Qingqing Chen ${ }^{1} \cdot$ Jan P. Bakker ${ }^{1} \cdot$ Juan Alberti $^{2} \cdot$ Christian Smit $^{1}$ \\ Received: 24 October 2019 / Revised: 21 March 2020 / Accepted: 31 March 2020 / \\ Published online: 9 April 2020 \\ (c) The Author(s) 2020
}

\begin{abstract}
Evaluation of long-term management regimes is important for guiding biodiversity conservation in salt marshes. However, such long-term experiments are sparse. Using a 46-year experiment in a salt marsh, we evaluated long-term effects of eight different management regimes (treatments; control, grazing, mowing, and their combinations) on the expansion of a late successional plant species (Elytrigia atherica), plant species richness and diversity, and community composition (species identities and dominance structure). Results show that $E$. atherica expanded strongly over time in the control treatment (without grazing or mowing) while plant species richness and diversity declined substantially. By contrast, E. atherica was greatly suppressed while plant species richness and diversity remained relatively unchanged in all other treatments except for the mowing, where species richness declined in the late season mowing treatment and plant diversity declined after 17 years in the both early and late season mowing treatment. Therefore, all management types except for the mowing were effective in conserving plant diversity. The trends for change in species identities reversed: change in species identities accumulated in the control treatment and exceeded that of other treatments 15 years after the start of the experiment. This suggests that results based on shorter-term $(<15$ years $)$ experiments may provide misleading conservation recommendations. Also, trends for change in dominance structure (taking abundance into account) were substantially different from those for species identities. Our results highlight the importance of long-term monitoring for guiding conservation management, and that monitoring should not only focus on the number of species but also community composition, to fully identify critical changes.
\end{abstract}

Keywords Grazing · Livestock · Mowing · Vegetation succession · Community composition

Communicated by Daniel Sanchez Mata.

This article belongs to the Topical Collection: Coastal and marine biodiversity.

Electronic supplementary material The online version of this article (https://doi.org/10.1007/s10531-020-0 1976-w) contains supplementary material, which is available to authorized users.

$\bowtie$ Qingqing Chen

chqq365@hotmail.com

Extended author information available on the last page of the article 


\section{Introduction}

Grazing and mowing are among the most widely used management tools for conserving biodiversity in terrestrial grasslands and salt marshes worldwide (Davidson et al. 2017; Gedan et al. 2009; Tälle et al. 2016). The effects of grazing on plant and insect communities (diversity and composition) have been well-documented in salt marshes (Bakker et al. 2019; Bos et al. 2002; Burkepile et al. 2017; Ford et al. 2013; Kiehl et al. 1996; Pétillon et al. 2007; Rickert et al. 2012; Van Klink et al. 2016). However, mowing has become less common in salt marshes in recent decades (Bakker et al. 2002b; Gedan et al. 2009; but see Bakker 1978; Pétillon et al. 2007). Short-term studies ( $<15$ years) from terrestrial grasslands comparing grazing and mowing (yearly) on plant diversity show inconsistent results. Some studies show that grazing is better than mowing (Bakker 1985; De Cauwer and Reheul 2009; During and Willems 1984; Fritch et al. 2011; Herbst et al. 2013; Jacquemyn et al. 2003), some show that mowing is better than grazing (Catorci et al. 2014; Stammel et al. 2003; Tälle et al. 2015), while others show that both have similar effects (e.g. Wellstein et al. 2007). Also, results from grasslands suggest the timing and frequency of mowing can modify the effects of mowing on plant diversity (Bakker et al. 2002a; De Cauwer and Reheul 2009; Dee et al. 2016). To our knowledge, studies, particularly the long-term ones (decades long), from salt marshes comparing grazing, different timing and frequency of mowing, and their combinations on plant diversity are rare.

The Wadden Sea salt marshes, representing ca. $20 \%$ of the total coastal salt marshes in Europe (Esselink et al. 2017), have traditionally been used for livestock grazing and, to a lesser extent, mowing (haymaking) (Bakker et al. 2002b). In the past decades, livestock grazing reduced or ceased in salt marshes as agriculture and economic interest decreased while conservation interest gained in importance (Bakker et al. 2003). However, cessation of grazing led to the local dominance, for instance, by the late successional tall grass, Elytrigia atherica (synonym Elymus athericus), particularly in the higher marshes (Veeneklaas et al. 2013), or Atriplex portulacoides in the lower marshes (Wanner et al. 2014), or Phragmites australis in brackish coastal marshes (Sammul et al. 2012). Increased dominance is usually accompanied by a decline in plant diversity (Koerner et al. 2018), which in turn can reduce ecosystem functioning, for instance, lower productivity (Tilman et al. 2001) and resilience to climate extremes or other anthropogenic environmental changes (Hautier et al. 2015; Isbell et al. 2015). To reverse this trend, different management regimes, usually focusing on different grazers and grazing intensity, were introduced (e.g. Bakker et al. 2019; Van Klink et al. 2016; Wanner et al. 2014). However, which management (including not only grazing but also mowing) is optimal for conserving biodiversity in salt marshes, particularly in the long term, remains debated (e.g. Van Klink et al. 2016).

Using a 46-year experiment in a Wadden Sea salt marsh, we evaluated the long-term effects of different management regimes (undisturbed control, grazing, early and late season mowing, and their combinations) on the expansion of the dominant grass E. atherica, plant species richness and diversity. Also, we evaluated these effects on community composition (species identities and dominance structure), given that the identities and abundance of the plant species can sometimes be as important as diversity in delivering ecosystem functioning and services (e.g. Winfree et al. 2015). 


\section{Materials and methods}

\section{Study site and experimental design}

The Wadden Sea salt marshes have high conservation value as they harbor a wealth of plant and animal species, some of which are endemic to this area. These salt marshes are therefore protected under the EU Habitats Directive (EC Habitats Directive 1992). The experiment was conducted in one of these salt marshes, the natural high productive $(1120 \pm 201 \mathrm{~g} \mathrm{dw}$ $\mathrm{m}^{-2}$; mean \pm 1 se; measured in 2018) salt marsh in the barrier island of Schiermonnikoog $\left(53^{\circ} 30^{\prime} \mathrm{N}, 6^{\circ} 10^{\prime} \mathrm{E}\right)$, the Netherlands (Bakker 1985). A small western part of the salt marsh had been grazed by cattle up to 1958 when grazing stopped. Cessation of grazing led to the local dominance of the tall late successional grass, E. atherica, which led to a decline in plant diversity over the following 10 years (Bakker 1985). The conservation managers wanted to reverse this trend. Hence, a field experiment to guide management practices started in 1972 in this area.

Four blocks were established in 1972, encompassing different plant communities characterized by different dominant species: block (1) Festuca rubra and Armeria maritima; block (2) E. atherica; block (3) F. rubra and Artemisia maritima; block (4) F. rubra and Limonium vulgare. Block 1 and 2 were situated in high marsh, block 3 and 4 in the low marsh. Exclosures (ca. $8 \mathrm{~m} \times 42 \mathrm{~m}$ ) within blocks, consisted of two electrical metal strands running 0.5 and $1 \mathrm{~m}$ above ground supported by wooden posts every $3.5 \mathrm{~m}$. Note that small herbivores like hares, geese, and insects could enter the exclosures freely. Hares and geese can substantially slow down species decline over time particularly when their abundance is high (Chen et al. 2019). A previous study using this experiment shows that cattle grazing facilitates hare grazing, and possibly also goose grazing, because cattle graze down the tall grass $E$. atherica, which in turn promotes $F$. rubra favored by hares and geese (Kuijper et al. 2008). Each block contained eight different treatments, including (1) an undisturbed control (C, i.e. natural succession without grazing and mowing), (2) early season mowing (M (E)), (3) late season mowing (M (L)), (4) both early and late season mowing (M (EL)), (5) grazing by cattle $(G),(6)$ grazing plus early season mowing $(G+M(E))$, (7) grazing plus late season mowing $(\mathrm{G}+\mathrm{M}(\mathrm{L}))$, (8) grazing plus both early and late season mowing $(\mathrm{G}+\mathrm{M}(\mathrm{EL}))$ (plot size ca. $18 \mathrm{~m}^{2}$ for mowing treatments; experimental design in Fig. S1). Treatments within blocks were randomized in the field. We usually mowed in late June or early July for the early season mowing, and in late August or early September for the late season mowing. We cut the vegetation to $2 \mathrm{~cm}$ above ground using a brush cutter. Plant material (including litter) was raked and collected, and dry weight was determined. Cattle grazing was continuous from May to November annually. Stocking density decreased from 1.5 to $0.5 \mathrm{head} \mathrm{ha}^{-1}$ from 1993 onwards, as the cattle-grazed area increased (Bakker et al. 1993; Bos et al. 2002; Fig. S1). One permanent plot $(2 \mathrm{~m} \times 2 \mathrm{~m})$ for each treatment was established in 1972 . We recorded species occurrence and abundance in the permanent plots before the start of mowing from 1972 to 2017. We used the data from 1972, 1974-1980, 1984-1989, 2003, 2015 and 2017, as all the eight treatments were measured in those years (thus 17 years of surveys). We estimated abundance (percent cover) using the decimal scale of Londo (1976). As we estimated percent cover for each species independently, the total cover of living plants can sometimes exceed $100 \%$ for the multilayer canopies. Plant species occurrence and abundance were recorded by a skilled field assistant for most years. A list of plant species occurred during the 46-year experiment can be found in Table $\mathrm{S} 1$. 


\section{Data analysis}

\section{Elytrigia atherica, Festuca rubra, and dominance}

We explored temporal trends of percent cover of E. atherica and F. rubra in different treatments. We included F. rubra as it is the most dominant intermediate successional species in this salt marsh, and is replaced by E. atherica as the marsh ages. To check whether the change in abundance of these two dominant grasses was the main cause for change in dominance, we also explored the temporal trends of dominance using the Berger-Parker dominance index, and 1-evenness. Berger-Parker dominance index is measured as the proportional abundance of the most abundant species. Evenness was calculated as H/ln (S), where H is Shannon's diversity index, and $\mathrm{S}$ is species richness. Dominance calculated as 1 -evenness takes the abundance of all species into account. Temporal trends of dominance were similar using the Berger-Parker dominance index and 1-evenness. We therefore only presented the result of the Berger-Parker dominance index in the main text.

\section{Species richness and plant diversity}

We explored temporal trends of species richness and plant diversity. Species richness was measured as the number of species recorded within each permanent plot. Plant diversity was measured as Shannon's index $(\mathrm{H})$, taking into account the abundance of each plant species.

\section{Community composition (identities and dominance structure)}

We focused on change in community composition relative to its initial state in each treatment, thus the stability of community composition. We compared a community (in a permanent plot) in each year with that of the starting year 1972. We explored change in community composition based on the species presence /absence data (identities), and abundance data (dominance structure). We used function beta.pair and beta.pair.abund from the R package betapart (Baselga and Orme 2012; Baselga 2013) for change in species identities and dominance structure, respectively. We specified Sørensen index and Bray-Curtis dissimilarity index in these two functions, respectively. For the change in species identities (ranging from 0 to 1 ), when it approaches 0 , species identities in a community in a later year are completely the same as that of the community in 1972, and when it approaches 1, species identities are completely different. Similarly, for the dominance structure, 0 suggests that species identities and their abundances in a community in a later year are completely the same as that of the community in 1972, while 1 suggests that species identities and/or their abundances are completely different.

We used gamm models from package mgcv (Wood 2017) to fit the temporal trends. In all the models except for E. atherica, treatment was the fixed variable, and smooths were fitted for each treatment, with block and permanent plot as random variables. Temporal autocorrelation was adjusted using the corCAR 1 model for unevenly spaced time series data. For E. atherica, there were too many zeros (299 of 544) in the data, and currently, package mgcv has not implemented a zero_inflated_beta distribution. Another package, brms (Bürkner 2017), implements this distribution, however, it does not implement autocorrelation for unevenly spaced time series data. Therefore, for E. atherica (gamm) model, we used the averaged percent cover data (across four blocks). In this model, treatment was the fixed variable, smooths were fitted for each treatment, and no random variable was specified, while 
autocorrelation was specified to each treatment. Percent cover of E. atherica was fourth-root transformed, and percent cover of $F$. rubra was square-root transformed before fitting the models to improve the normality of the residuals and homogeneity of variance. We used family quasipoisson for the species richness (count data) model to account for overdispersion. We extracted the parametric coefficients and smooth terms from these models to assess the overall effects (averaged across 46 years; Table S2) and over-time effects (the trends are significant when $\mathrm{p}<0.05$; Table S3) for the different treatments. For the overall effects, we particularly focused on comparing other treatments to the control, as the control treatment was treated as the reference in these models. Data analysis was performed using R 3.5.1 (R Core Team 2018).

\section{Results}

\section{Elytrigia atherica, Festuca rubra, and dominance}

Overall, compared with the control, E. atherica decreased significantly in all other treatments (estimated from gamm models using data across 46 years; Table S2). Over time, E. atherica expanded strongly in the control treatment, while it remained low in all other treatments (percent cover $<20 \%$ on average; Fig. 1a). Overall, compared with the control treatment, $F$. rubra increased in the mowing treatments (nearly significant in the both early and late season mowing treatment) (Table S2). Over time, F. rubra decreased in the control treatment, while it generally increased in all mowing treatments. It also increased in the grazing treatment, and the grazing plus both early and late season mowing after 2010 (Fig. 1b; Table S3). In general, the pattern of dominance matched well with those changes in E. atherica and $F$. rubra. Overall, compared with the control, dominance decreased significantly in all other treatments (Table S2). Over time, dominance increased in the control, and in the both early and late season mowing treatment (Fig. 1c; Table S3).

\section{Plant species richness and diversity}

Overall, compared with the control, species richness and plant diversity increased significantly in all other treatments (Table S2). Over time, species richness declined in the control and the late season mowing treatments, it remained relatively unchanged in other treatments, except for the grazing plus early season mowing treatment where species richness varied (Fig. 2a; Table S3). Over time, plant diversity decreased in the control, it also decreased in the both early and late season mowing treatment after 1989, it remained relatively unchanged in other treatments (Fig. 2b; Table S3).

\section{Change in the species identities and dominance structure}

Overall, compared with the control treatment, change in species identities did not differ significantly in the other treatments (Table S2). Over time, species identities changed substantially in all treatments except for the grazing plus mowing treatments. Particularly, species identities changed strongly (relative to its initial state) in the control treatment 15 years after the start of the experiment (Table S3; Fig. 3a). Overall, compared with the control treatment, the dominance structure was significantly higher in the grazing plus both early and late season mowing treatment (Table S2). Over time, the dominance structure changed substantially in 

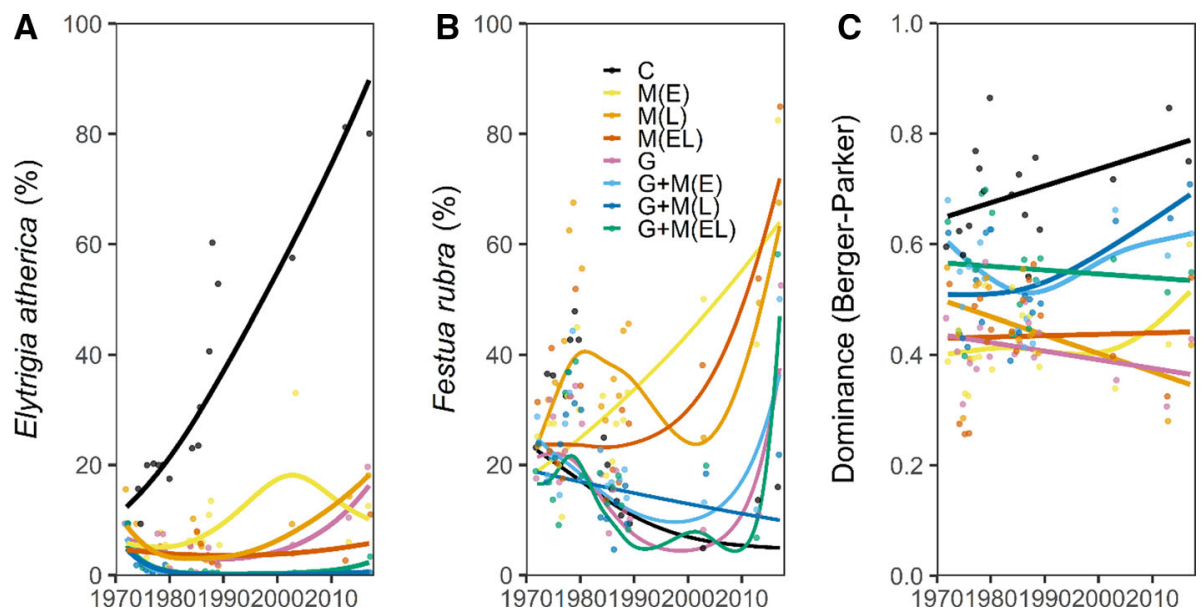

Fig. 1 Percent cover of Elytrigia atherica, Festuca rubra and dominance in different treatments during the 46-year experiment. Dots are the means of four blocks. Lines are fitted with generalized additive mixed model (gamm; Table S3). Berger-Parker dominance index is measured as the proportional abundance of the most abundant species. C: control, i.e. natural succession without grazing and mowing; $\mathrm{M}(\mathrm{E})$ : early season mowing; M (L): late season mowing; $M(E L)$ : both early and late season mowing; G: cattle grazing; $G+M(E)$ : cattle grazing plus early season mowing; $G+M(L)$ : cattle grazing plus late season mowing; $G+M(E L)$ : cattle grazing plus both early and late season mowing
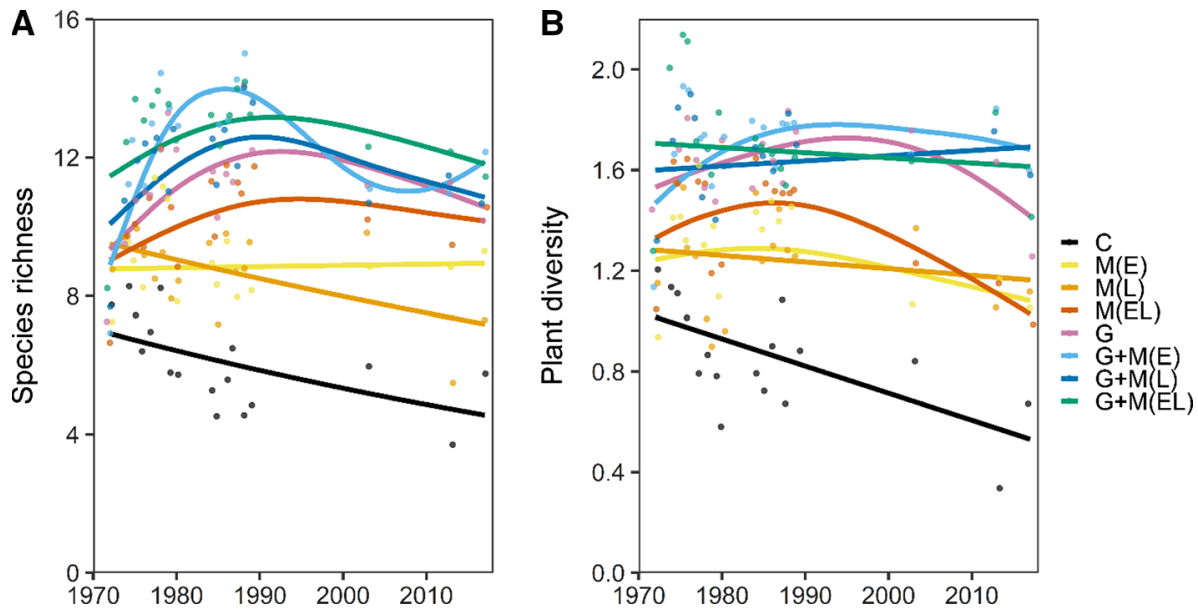

Fig. 2 Plant species richness and diversity in different treatments during the 46-year experiment. Dots are the means of four blocks. Lines are fitted with generalized additive mixed model (gamm; Table S3). Species richness was measured as the number of species recorded within the permanent plots $(2 \mathrm{~m} \times 2 \mathrm{~m})$. Plant diversity was measured as Shannon's index $(\mathrm{H})$. Treatment description corresponds to that of Fig. 1

all treatments (Table S3; Fig. 3b), except for the grazing plus late season mowing treatments. It suggests that the plant species abundances were highly variable over time. Particularly, the dominance structure was much higher in the grazing plus both early and late season mowing treatment and, to a lesser extent, in the grazing plus early season mowing treatment than in the other treatments (Fig. 3b). 

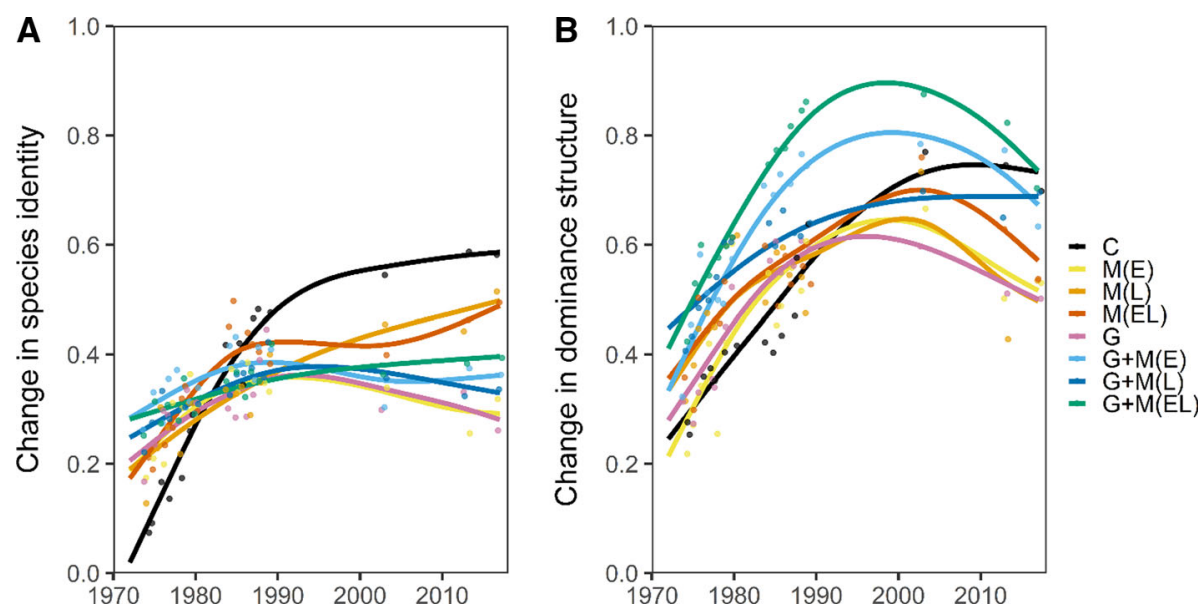

Fig. 3 Change in species identities and dominance structure in different treatments during the 46-year experiment. Dots are the means of four blocks. Lines are fitted with generalized additive mixed model (gamm; Table S3). For the change in species identities (ranging from 0 to 1), when it approaches 0 , species identities in a community in a later year are completely the same as that of the community in 1972, when it approaches 1 , species identities are completely different. Similarly, for the dominance structure, 0 suggests that species identities and their abundances in a community in a later year are completely the same as that of the community in 1972, while 1 suggests that species identities and/or their abundances are completely different. Treatment description corresponds to that of Fig. 1

\section{Discussion}

Our 46-year experiment evaluating long-term effects of eight different management regimes on plant communities suggests that long-term management is needed to suppress the expansion of the dominant grass E. atherica, and to conserve plant diversity in this salt-marsh ecosystem. Compared with the undisturbed control (without grazing or mowing), E. atherica was strongly suppressed in all other treatments while plant species richness and diversity remained relatively unchanged except for the mowing treatments. The trends for the change in species identities reversed: species identities in the control treatment changed less over time relative to its initial state in 1972 than any other treatments during the first 8 years, but changed more than all other treatments 15 years after the start of the experiment. In addition, the trends for change in dominance structure (taking abundance into account) were substantially different from those for change in species identities. Our results have important implications for plant diversity conservation in salt marshes. Our results also emphasize the importance of running experiments for long term to fully evaluate the effects of different management regimes on plant communities.

\section{The dominance of Elytrigia atherica}

In the control treatment, where no grazing or mowing management was imposed, E. atherica expanded strongly during the 46-year experiment. It suggests that in this salt marsh natural vegetation succession may lead to the dominance of this grass. Valéry et al. (2017) found that eutrophication (nitrogen enrichment) is the major driver of the rapid expansion of this grass in French salt marshes. However, Bockelmann and Neuhaus (1999) found that increasing nitrogen availability, similar to the amount of annual atmospheric input, does not significantly 
impact the growth and expansion of E. atherica to the lower marsh in one of the Wadden Sea salt marshes. Also, Nolte et al. (2019) found that the increased elevation due to sediment accumulation, but not increased nitrogen availability, facilitates the expansion of E. atherica in another Wadden Sea salt marsh. Therefore, eutrophication may not play an important role in the expansion of this grass in Wadden Sea salt marshes. The block dominated by $E$. atherica at the start of this experiment remained dominated by this grass during the entire 46-year experiment (Fig. S2B). This indicates that the plant community dominated by $E$. atherica reaches a stable state. Increased dominance of $E$. atherica without disturbance has also been widely observed in other salt marshes across Europe (Milotić et al. 2010; Pétillon et al. 2005; Rupprecht et al. 2015; Van Klink et al. 2016; Wanner et al. 2014). This dominance of E. atherica in salt marshes is, however, undesired, as it leads to a decline in plant diversity. Compared with the control treatment, all other treatments substantially suppressed the dominant grass, E. atherica. Particularly, grazing plus any combination of mowing suppressed E. atherica the most in the block originally dominated by this grass 46 years after the start of the experiment (Fig. S2A). It suggests that for restoring plant communities dominated by this grass, grazing plus any combination of mowing may be more effective than grazing or mowing alone.

\section{Species richness and plant diversity}

Over time, plant species richness and diversity remained relatively unchanged in all treatments except for the control and mowing treatments. Species richness declined in the late season mowing treatment, plant diversity declined in both the early and late season mowing 17 years after the start of the experiment, likely due to the increased dominance (Fig. 1c; Koerner et al. 2018). Plant diversity also appeared to decline in the early season mowing and late season mowing treatment, although these trends were not statistically significant. These trends exist maybe because the intermediate successional grass, $F$. rubra, increased the dominance in these mowing treatments once the late successional grass E. atherica was suppressed (Fig. 1). However, different dominant species have different effects on species richness (During and Willems 1984). Wanner et al. (2014) demonstrated that species richness decreased by 2.5 species on average in $1-\mathrm{m}^{2}$ plots dominated (percent cover more than $30 \%$ ) by E. atherica 20 years after the start of the experiment in a Wadden Sea salt marsh, while species richness decreased by less than 1 species on average in plots dominated by F. rubra. Lepš (2014) also reported that mowing was only able to mitigate plant species loss induced by fertilization in the short term in a 15-year field experiment in a species-rich grassland. Together, mowing may be a more suitable management tool for conserving plant diversity in the shorter term.

\section{Community composition}

Community composition based on presence/absence (species identities) and abundance data (dominance structure) showed different trends. Change in species identities remained relatively stable (relative to its initial state in 1972) over time in the grazing plus early season mowing, and the grazing plus both early and late season mowing treatments. However, the dominance structure in these two treatments changed substantially. This indicates that the species responsible for these changes were the more common or abundant species in these two treatments. This further suggests that small changes in the species identities can occur along with substantial changes in the dominance structure, which may substantially change ecosystem functioning (Winfree et al. 2015). Our results, therefore, support the idea that con- 
servation should not only monitor species richness but also include changes in community composition (e.g. Dornelas 2014; Hillebrand et al. 2018).

\section{Effects of management regimes on environmental variables}

Different treatments also had a different impact on environmental variables. In this study area, Schrama et al. (2013) found that, compared with the control and the late season mowing treatments, long-term cattle grazing strongly increases soil bulk density, increases carbon stock, while it reduces soil redox potential, soil macrofauna abundance, and nitrogen mineralization. This suggests that long-term cattle grazing - due to trampling, deposition of urine and dung-has profound effects on soil properties and nutrient cycling. In addition, these alterations of soil properties and nutrient cycling may have feedback on plant communities (Mikola et al. 2009), thus contribute to the observed changes in this experiment.

\section{Comparing with salt marshes outside Europe}

Compared with European salt marshes, livestock grazing is less common in America and Asia (Davidson et al. 2017; Gedan et al. 2009), while mowing is generally rare nowadays (Gedan et al. 2009). This makes it difficult to compare our results with salt marshes in America and Asia. The effects of grazing on plant diversity may be less apparent or negative in America (e.g. Wasson and Woolfolk 2011; Di Bella et al. 2014), because salt marshes in America are usually dominated by one or a few plant species (Conde et al. 2006; Pennings et al. 2001). By contrast, salt marshes in Europe harbor more plant diversity (Bakker et al. 2015). Also, grazing tends to decrease soil carbon stock in America, but not in Europe (Davidson et al. 2017). This may be due to different soil formation: European salt marshes are mainly derived from mineral deposition while American marshes are from organic material (Bakker et al. 2015). Hence, our results and implications for conservation management typically apply to European salt marshes.

To conclude, our results suggest that long-term experiments are important, and long-term management is needed to conserve plant diversity in this salt-marsh system. Overall, all the management regimes tested were effective in plant diversity conservation in this salt marsh. However, mowing may be more suitable in the shorter term. Grazing can substantially alter soil properties and nutrient cycling compared with mowing. Grazing plus early season mowing, and grazing plus both early and late season mowing may not be suitable if maintaining stability in the dominance structure is desired.

Acknowledgements We thank Natuurmonumenten for offering us the opportunity to work in the salt marsh of the island of Schiermonnikoog. We thank Yzaak de Vries for recording the occurrence and abundance of plant species in permanent plots for many years. We thank Richard Ubels for helping record the occurrence and abundance of plant species in 2017. We thank Jacob Hogendorf and Jan van den Burg for the help in the field. We thank Ido Pen for the discussion in data analysis. QC is funded by CSC (China Council Scholarship). JA was supported by a Visitor's Travel Grant (040.11.631) of the Netherlands Organization for Scientific Research (NWO).

Author contributions JB designed and conducted the experiments. CS and QC collected data since 2012, and 2016, respectively. QC and JA discussed the data analysis and set the conceptual framework of this manuscript. QC analyzed the data and wrote the manuscript. All authors contributed to the revisions and gave final approval for publication. 
Open Access This article is licensed under a Creative Commons Attribution 4.0 International License, which permits use, sharing, adaptation, distribution and reproduction in any medium or format, as long as you give appropriate credit to the original author(s) and the source, provide a link to the Creative Commons licence, and indicate if changes were made. The images or other third party material in this article are included in the article's Creative Commons licence, unless indicated otherwise in a credit line to the material. If material is not included in the article's Creative Commons licence and your intended use is not permitted by statutory regulation or exceeds the permitted use, you will need to obtain permission directly from the copyright holder. To view a copy of this licence, visit http://creativecommons.org/licenses/by/4.0/.

\section{References}

Bakker JP (1978) Changes in a salt-marsh vegetation as a result of grazing and mowing? a five-year study of permanent plots. Vegetatio 38(2):77-87

Bakker JP (1985) The impact of grazing on plant communities, plant populations and soil conditions on salt marshes. Vegetatio 62:391-398. https://doi.org/10.1007/BF00044766

Bakker JP, De Vlas J, Van Tooren BF (1993) Uitbreiding begrazing van de Oosterkwelder op Schiermonnikoog. Levende Nat 94:118-122

Bakker JP, Elzinga JA, de Vries Y (2002a) Effects of long-term cutting in a grassland system: perspectives for restoration of plant communities on nutrient-poor soils. Appl Veg Sci 5:107-120. https://doi.org/10.111 1/j.1654-109X.2002.tb00540.x

Bakker JP, Esselink P, Dijkema KS, Van Duin WE, De Jong DJ (2002b) Restoration of salt marshes in the Netherlands. Hydrobiologia 478:29-51. https://doi.org/10.1023/A:1021066311728

Bakker JP, Bos D, de Vries Y (2003) To graze or not to graze: that is the question. In: Challenges to Wadden Sea-proc. 10th int. sci. wadden sea symp, pp 67-87.

Bakker JP, Nielsen KJ, Alberti J et al (2015) Bottom-up and top- down interactions in coastal interface systems. In: Hanley TC, La Pierre KJ (eds) Trophic ecology: bottom-up and top-down interactions across aquatic and terrestrial systems. Cambridge University Press, Cambridge, pp 157-200

Bakker JP, Schrama M, Esselink P, Daniels P, Bhola N, Nolte S, de Vries Y, Veeneklaas RM, Stock M (2019) Long-term effects of sheep grazing in various densities on marsh properties and vegetation dynamics in two different salt-marsh zones. Estuar Coasts 43:298-315. https://doi.org/10.1007/s12237-019-00680-5

Baselga A (2013) Separating the two components of abundance-based dissimilarity: balanced changes in abundance vs. abundance gradients. Methods Ecol Evol 4:552-557

Baselga A, Orme CDL (2012) Betapart: an R package for the study of beta diversity. Methods Ecol Evol 3:808-812

Bockelmann AC, Neuhaus R (1999) Competitive exclusion of Elymus athericus from a high-stress habitat in a European salt marsh. J Ecol 87:503-5013

Bos D, Bakker JP, De Vries Y, Van Lieshout S (2002) Long-term vegetation changes in experimentally grazed and ungrazed back-barrier marshes in the Wadden Sea. Appl Veg Sci 5:45-54. https://doi.org/10.1658/1 402-2001

Burkepile DE, Fynn RWS, Thompson DI, Lemoine NP, Koerner SE, Eby S, Hagenah N, Wilcox KR, Collins SL, Kirkman KP, Knapp AK, Smith MD (2017) Herbivore size matters for productivity-richness relationships in African savannas. J Ecol 105:674-686. https://doi.org/10.1111/1365-2745.12714

Bürkner P (2017) Brms: an R Package for bayesian multilevel models using stan. J Stat Softw 80(1):1-28. https://doi.org/10.18637/jss.v080.i01

Catorci A, Cesaretti S, Malatesta L, Tardella FM (2014) Effects of grazing vs mowing on the functional diversity of sub-Mediterranean productive grasslands. Appl Veg Sci 17:658-669. https://doi.org/10.111 1/avsc. 12103

Chen Q, Howison RA, Bakker JP, Alberti J, Kuijper DPJ, Olff H et al (2019) Small herbivores slow down species loss up to 22 years but only at early successional stage. J Ecol 107:2688-2696

Conde D, Isacch JP, Costa CSB, Escapa M, Gagliardini DA, Iribarne OO (2006) Distribution of saltmarsh plant communities associated with environmental factors along a latitudinal gradient on the south-west Atlantic coast. J Biogeogr 33:888-900. https://doi.org/10.1111/j.1365-2699.2006.01461.x

Davidson KE, Fowler MS, Skov MW, Doerr SH, Beaumont N, Griffin JN (2017) Livestock grazing alters multiple ecosystem properties and services in salt marshes: a meta-analysis. J Appl Ecol 54:1395-1405. https://doi.org/10.1111/1365-2664.12892

De Cauwer B, Reheul D (2009) Impact of land use on vegetation composition, diversity and potentially invasive, nitrophilous clonal species in a wetland region in Flanders. Agron Sustain Dev 29:277-285. https://doi.org/10.1051/agro:2008049 
Dee JR, Thomas SM, Thompson SD, Palmer MW (2016) Long-term late season mowing maintains diversity in southern US tallgrass prairie invaded by Bothriochloa ischaemum. Appl Veg Sci 19:442-453. https:// doi.org/10.1111/avsc. 12227

Di Bella CE, Jacobo E, Golluscio RA, Rodríguez AM (2014) Effect of cattle grazing on soil salinity and vegetation composition along an elevation gradient in a temperate coastal salt marsh of Samborombón Bay (Argentina). Wetl Ecol Manag 22:1-13. https://doi.org/10.1007/s11273-013-9317-3

Dornelas M (2014) Assemblage time series reveal biodiversity change but not systematic loss. Science 344:296-300. https://doi.org/10.1126/science.1248484

During AHJ, Willems JH (1984) Diversity models applied to a chalk grassland. Vegetatio 57:103-114

EC Habitats Directive (1992) Council directive 92/43/EEC of 21 May 1992 on the conservation of natural habitats and of wild fauna and flora

Esselink P, van Duin WE, Bunje J, Cremer J, Folmer EO, Frikke J, Glahn M, de Groot AV, Hecker N, Hellwig U, Jensen K, Körber P, Petersen J, Stock M (2017) Salt marshes. In: Kloepper S. et al., (eds) Common wadden sea secretariat, Wadden Sea quality status report 2017. Wilhelmshaven, Germany. Last updated 21.12.2017. https://https://qsr.waddensea-worldheritage.org/reports/salt-marshes

Ford H, Garbutt A, Jones L, Jones DL (2013) Grazing management in saltmarsh ecosystems drives invertebrate diversity, abundance and functional group structure. Insect Conserv Divers 6:189-200

Fritch RA, Sheridan H, Finn JA, Kirwan L, Uallacháin DO (2011) Methods of enhancing botanical diversity within field margins of intensively managed grassland: a 7-year field experiment. J Appl Ecol 48:551-560. https://doi.org/10.1111/j.1365-2664.2010.01951.x

Gedan KB, Silliman BR, Bertness MD (2009) Centuries of human-driven change in salt marsh ecosystems. Ann Rev Mar Sci 1:117-141. https://doi.org/10.1146/annurev.marine.010908.163930

Hautier Y, Tilman D, Isbell F, Seabloom EW, Borer ET, Reich PB (2015) Anthropogenic environmental changes affect ecosystem stability via biodiversity. Science 348(6232):336-340. https://doi.org/10.112 6/science.aaa1788.

Herbst C, Wäschke N, Barto EK, Arnold S, Geuß D, Halboth I, Reschke S, Sänger J, Meiners T, Obermaier E (2013) Land use intensification in grasslands: higher trophic levels are more negatively affected than lower trophic levels. Entomol Exp Appl 147:269-281. https://doi.org/10.1111/eea.12072

Hillebrand H, Blasius B, Borer ET, Chase JM, Downing JA, Eriksson BK, Filstrup CT, Harpole WS, Hodapp D, Larsen S, Lewandowska AM, Seabloom EW, Van de Waal DB, Ryabov AB (2018) Biodiversity change is uncoupled from species richness trends: consequences for conservation and monitoring. $\mathrm{J}$ Appl Ecol 55:169-184. https://doi.org/10.1111/1365-2664.12959

Isbell F, Craven D, Connolly J, Loreau M, Schmid B, Beierkuhnlein C, Bezemer TM, Bonin C, Bruelheide H, de Luca E, Ebeling A, Griffin JN, Guo Q, Hautier Y, Hector A, Jentsch A, Kreyling J, Lanta V, Manning P, Meyer ST, Mori AS, Naeem S, Niklaus PA, Polley HW, Reich PB, Roscher C, Seabloom EW, Smith MD, Thakur MP, Tilman D, Tracy BF, van der Putten WH, van Ruijven J, Weigelt A, Weisser WW, Wilsey B, Eisenhauer N (2015) Biodiversity increases the resistance of ecosystem productivity to climate extremes. Nature 526(7574):574-577

Jacquemyn H, Brys R, Hermy M (2003) Short-term effects of different management regimes on the response of calcareous grassland vegetation to increased nitrogen. Biol Conserv 111:137-147. https://doi.org/10. 1016/S0006-3207(02)00256-2

Kiehl K, Eischeid I, Gettner S, Walter J (1996) Impact of different sheep grazing intensities on salt marsh vegetation in northern Germany. J Veg Sci 7:99-106. https://doi.org/10.2307/3236421

Koerner SE, Smith MD, Burkepile DE, Hanan NP, Avolio ML, Collins SL, Knapp AK, Lemoine NP, Forrestel EJ, Eby S, Thompson DI, Aguado-Santacruz GA, Anderson JP, Anderson TM, Angassa A, Bagchi S, Bakker ES, Bastin G, Baur LE, Beard KH, Beever EA, Bohlen PJ, Boughton EH, Canestro D, Cesa A, Chaneton E, Cheng J, D’Antonio CM, Deleglise C, Dembélé F, Dorrough J, Eldridge DJ, FernandezGoing B, Fernández-Lugo S, Fraser LH, Freedman B, García-Salgado G, Goheen JR, Guo L, Husheer S, Karembé M, Knops JMH, Kraaij T, Kulmatiski A, Kytöviita M-M, Lezama F, Loucougaray G, Loydi A, Milchunas DG, Milton SJ, Morgan JW, Moxham C, Nehring KC, Olff H, Palmer TM, Rebollo S, Riginos C, Risch AC, Rueda M, Sankaran M, Sasaki T, Schoenecker KA, Schultz NL, Schütz M, Schwabe A, Siebert F, Smit C, Stahlheber KA, Storm C, Strong DJ, Su J, Tiruvaimozhi YV, Tyler C, Val J, Vandegehuchte ML, Veblen KE, Vermeire LT, Ward D, Wu J, Young TP, Yu Q, Zelikova TJ (2018) Change in dominance determines herbivore effects on plant biodiversity. Nat Ecol Evol 2:1925-1932. https://doi.org/10.1038/s41559-018-0696-y

Kuijper DPJ, Beek P, van Wieren SE, Bakker JP (2008) Time-scale effects in the interaction between a large and a small herbivore. Basic Appl Ecol 9:126-134. https://doi.org/10.1016/j.baae.2006.08.008

Lepš J (2014) Scale- and time-dependent effects of fertilization, mowing and dominant removal on a grassland community during a 15-year experiment. J Appl Ecol 51:978-987

Londo G (1976) The decimal scale for releves of permanent quadrats. Vegetatio 33(1):61-64 
Mikola J, Setälä H, Virkajärvi P, Saarijärvi K, Ilmarinen K, Voigt W et al (2009) Defoliation and patchy nutrient return drive grazing effects on plant and soil properties in a dairy cow pasture. Ecol Monogr 79:221-244

Milotić T, Erfanzadeh R, Pétillon J, Maelfait JP, Hoffmann M (2010) Short-term impact of grazing by sheep on vegetation dynamics in a newly created salt-marsh site. Grass Forage Sci 65:121-132. https://doi.org/ 10.1111/j.1365-2494.2009.00725.x

Nolte S, Wanner A, Stock M, Jensen K (2019) Elymus athericus encroachment in Wadden Sea salt marshes is driven by surface elevation change. Appl Veg Sci 22:454-464

Pennings SC, Siska EL, Bertness MD (2001) Latitudinal differences in plant palatability in atlantic coast salt marshes. Ecology 82:1344-1359

Pétillon J, Ysnel F, Canard A, Lefeuvre JC (2005) Impact of an invasive plant (Elymus athericus) on the conservation value of tidal salt marshes in western France and implications for management: responses of spider populations. Biol Conserv 126:103-117. https://doi.org/10.1016/j.biocon.2005.05.003

Pétillon J, Georges A, Canard A, Ysnel F (2007) Impact of cutting and sheep grazing on ground-active spiders and carabids in intertidal salt marshes (Western France). Anim Biodivers Conserv 30:201-209

R Core Team (2018) R: a language and environment for statistical com-puting. Vienna, Austria: R foundation for statistical computing. Retrieved from https://www.R-project.org/

Rickert C, Fichtner A, van Klink R, Bakker JP (2012) A- and B-diversity in moth communities in salt marshes is driven by grazing management. Biol Conserv 146:24-31. https://doi.org/10.1016/j.biocon.2011.11.0 24

Rupprecht F, Wanner A, Stock M, Jensen K (2015) Succession in salt marshes-large-scale and long-term patterns after abandonment of grazing and drainage. Appl Veg Sci 18:86-98. https://doi.org/10.1111/ avsc. 12126

Sammul M, Kauer K, Köster T (2012) Biomass accumulation during reed encroachment reduces efficiency of restoration of Baltic coastal grasslands. Appl Veg Sci 15:219-230

Schrama M, Heijning P, Bakker JP, Van Wijnen HJ, Berg MP, Olff H (2013) Herbivore trampling as an alternative pathway for explaining differences in nitrogen mineralization in moist grasslands. Oecologia 172:231-243

Stammel B, Kiehl K, Pfadenhauer J (2003) Alternative management on fens: response of vegetation to grazing and mowing. Appl Veg Sci 6:245-254

Tälle M, Fogelfors H, Westerberg L, Milberg P (2015) The conservation benefit of mowing vs grazing for management of species-rich grasslands: a multi-site, multi-year field experiment. Nord J Bot 33:761-768. https://doi.org/10.1111/njb.00966

Tälle M, Deák B, Poschlod P, Valkó O, Westerberg L, Milberg P (2016) Grazing vs. mowing: a meta-analysis of biodiversity benefits for grassland management. Agric Ecosyst Environ 222:200-212. https://doi.org/ 10.1016/j.agee.2016.02.008

Tilman D, Reich PB, Knops J, Wedin D, Mielke T, Lehman CL (2001) Diversity and productivity in a long-term grassland experiment. Science 80(294):43-845

Van Klink R, Nolte S, Mandema FS, Lagendijk DDG, WallisDeVries MF, Bakker JP, Esselink P, Smit C (2016) Effects of grazing management on biodiversity across trophic levels - the importance of livestock species and stocking density in salt marshes. Agric Ecosyst Environ 235:329-339. https://doi.org/10.10 16/j.agee.2016.11.001

Valéry L, Radureau A, Lefeuvre J (2017) Spread of the native grass Elymus athericus in salt marshes of MontSaint-Michel bay as an unusual case of coastal eutrophication. J Coast Conserv 21:421-433. https://doi. org/10.1007/s11852-016-0450-Z

Veeneklaas RM, Dijkema KS, Hecker N, Bakker JP (2013) Spatio-temporal dynamics of the invasive plant species Elytrigia atherica on natural salt marshes. Appl Veg Sci 16:205-216. https://doi.org/10.1111/j. 1654-109X.2012.01228.x

Wanner A, Suchrow S, Kiehl K, Meyer W, Pohlmann N, Stock M, Jensen K (2014) Scale matters: impact of management regime on plant species richness and vegetation type diversity in Wadden Sea salt marshes. Agric Ecosyst Environ 182:69-79. https://doi.org/10.1016/j.agee.2013.08.014

Wasson K, Woolfolk A (2011) Salt marsh-upland ecotones in central california: vulnerability to invasions and anthropogenic stressors. Wetlands 31:389-402. https://doi.org/10.1007/s13157-011-0153-Z

Wellstein C, Otte A, Waldhardt R (2007) Seed bank diversity in mesic grasslands in relation to vegetation type, management and site conditions. J Veg Sci 18:153-162

Winfree R, Fox JW, Williams NM, Reilly JR, Cariveau DP (2015) Abundance of common species, not species richness, drives delivery of a real-world ecosystem service. Ecol Lett 18:626-635. https://doi.org/10.11 11/ele.12424

Wood SN (2017) Generalized additive models: an introduction with R, 2nd edn. Chapman and Hall/CRC, Boca Raton 
Publisher's Note Springer Nature remains neutral with regard to jurisdictional claims in published maps and institutional affiliations.

\section{Affiliations}

\section{Qingqing Chen ${ }^{1} \cdot$ Jan P. Bakker ${ }^{1}$. Juan Alberti ${ }^{2} \cdot$ Christian Smit $^{1}$}

1 Conservation Ecology Group, Groningen Institute for Evolutionary Life Sciences (GELIFES), University of Groningen, P.O. Box 11103, 9700 CC Groningen, The Netherlands

2 Laboratorio de Ecología, Instituto de Investigaciones Marinas y Costeras (IIMyC), Universidad Nacional de Mar del Plata, Consejo Nacional de Investigaciones Científicas y Técnicas (CONICET), CC 1260 Correo Central, B7600WAG Mar del Plata, Argentina 